\title{
Reliability and Validity of a Turkish Version of the Acceptance and Action Diabetes Questionnaire
}

\author{
Mehmet Emrah Karadere ${ }^{1} \bowtie$, Kaasım Fatih Yavuz ${ }^{2}$, Ece Yazla Asafov ${ }^{1}$, and Ferit Kerim Küçükler ${ }^{3}$ \\ ${ }^{1}$ Department of Psychiatry, Hitit University Faculty of Medicine, Corum, Turkey \\ ${ }^{2}$ Department of Psychology, Istanbul Medipol University, Istanbul, Turkey \\ ${ }^{3}$ Department of Endocrinology, Hitit University Faculty of Medicine, Corum, Turkey
}

\begin{abstract}
Objective The aim of this study is to perform validity and reliability examination of the Turkish form of Acceptance and Action Diabetes Questionnaire, and to investigate whether this scale is a measurement tool for evaluation of psychological flexibility levels in a sample of patients with diabetes in Turkey.

Methods This study was conducted with 105 patients. Turkish forms of the Beck Depression Inventory (BDI), Problem Areas in Diabetes Questionnaire (PAID), State-Trait Anxiety Inventory (STAI-I and STAI-II), Audit of Diabetes-Dependent Quality of Life (ADDQoL) and Turkish form of Acceptance and Action Diabetes Questionnaire (TAADQ) were applied. SPSS 20.0 and AMOS was used in statistical analysis.

Results $56.12 \%$ of the patients were female and the mean of age was $54(\mathrm{SD}= \pm 9.9)$ years. The mean duration of education was found $7.65(\mathrm{SD}=3.97)$ years. $74.8 \%$ of the patients most of whom $(83.3 \%, \mathrm{n}=85)$ had diabetes mellitus and the mean glycemic control calculated with $\mathrm{HbA1c}$ was $8.02 \pm 1.91$. According to the final fit indices, we found that the revised and corrected 9-item model was superior over the previous model. Cronbach Alpha coefficient of TAADQ was found as 0.836 .

Conclusion TAADQ is a valid and reliable assessment tool in Turkish population. So TAADQ will be a powerfull tool in assessing psychological flexibility in diabetes patients.

Psychiatry Investig 2019;16(6):418-424
\end{abstract}

Key Words Acceptance and action, Diabetes, Reliability and validity, Turkish version.

\section{INTRODUCTION}

Diabetes, which affects many systems as well as mental health, ${ }^{1}$ is a common disease ${ }^{2}$ and when considering the mortality and higher health care costs due to its management and treatment become important. Patients with diabetes are diagnosed with depression by 2 to 4 times more frequent compared to the non-diabetics. ${ }^{3-6}$ Recurrent physical and emotional burdens that often accompany diabetic self-management have been proposed to play an important role in the increased risk for depression. ${ }^{7}$ Because persons do not consider shortand long-term complications of the disease, they may have

Received: October 4, 2018 Revised: November 25, 2018 Accepted: February 26, 2019

$\triangle$ Correspondence: Mehmet Emrah Karadere, MD

Department of Psychiatry, Hitit University Faculty of Medicine, Bahçelievler Mh. Çamlık 2. Cd. No:1 Merkez-Çorum, Turkey

Tel: +90-00905332651664, Fax: +90 (364) 2193030

E-mail: karadere26@yahoo.com

(a) This is an Open Access article distributed under the terms of the Creative Commons Attribution Non-Commercial License (https://creativecommons.org/licenses/by$\mathrm{nc} / 4.0$ ) which permits unrestricted non-commercial use, distribution, and reproduction in any medium, provided the original work is properly cited. difficulty in acceptance of lifestyle changes, and encounter with depression, anxiety and similar psychiatric problems. ${ }^{8}$ Depression and anxiety disorders in diabetic persons are characterized by depressed mood, decreased energy and attention, sense of guilt, poor concentration, weight loss, decrease or increase in appetite, sleep disorders, thoughts of death and suicidal ideation and dysfunction. ${ }^{9}$

Treatment process of diabetes is often long and challenging. As in almost all chronic diseases, attitudes and approaches of person toward diabetes and its treatment may affect the prognosis. ${ }^{10}$ For example, it is known that acceptance of the disease and the difficulties it brings is challenging. ${ }^{11}$ Compliance to treatment in diabetes has been shown to increase glycemic control. ${ }^{12}$ High prevalence of negative psychological processes and the difficulties due to medical therapy process given raise to the need for development of psychotherapeutic interventions. Accordingly, possible effect of the cognitive-behavioral therapies (CBT) both on anxiety and depression, and on improvement of glycemic control have been studied in recent years. Reviews and meta-analyses including CBT studies on 
this issue indicate that CBT provided significant decreases in anxiety and depression levels, but did not show a substantial effect on glycemic control. ${ }^{13,14}$ However, Grey et al. ${ }^{15}$ achieved significant results such as lower glycosylated hemoglobin, higher diabetic and medical self-sufficiency, and decreased effect of diabetes on quality of life. Their group therapy protocol included 6 weekly sessions and monthly visits over the 12 months of follow up was applied to 77 patients with diabetes in 12-20 age group.

Some coping strategies have been found to have negative effects in stress reduction and providing ideal compliance to treatment during the treatment process. For example, a coping method like avoidance has been shown as a factor preventing compliance to treatment in diabetes. ${ }^{16}$ Supporting this result, non-acceptance of diabetes by the person has been found to be significantly associated with low active coping, decreased selfcare, high HbA1c levels, elevated diabetes related stress, and increased depressive symptoms. ${ }^{17}$ Again, high capacity of coping with the disease ${ }^{18}$ and low HbA1c levels ${ }^{19}$ have been shown in persons with high acceptance. In this direction, it has been found that acceptance-based new generation cognitive-behavioral therapies may be effective in diabetes management and associated mental problems. ${ }^{20,21}$ Unlike the traditional CBT approaches, Acceptance and Commitment Therapy (ACT) targets the development of acceptance and mindfulness strategies instead of control and elimination strategies toward negative experiences, skills of 'defusion' from verbal processes and exhibition of commitment in line with the values selected by the person. ${ }^{22}$ Within this context, goal of ACT is to develop the wellness model which is defined as psychological flexibility, in persons. Psychological flexibility can be defined as "the ability to contact the present moment fully to make contact with internal experiences-without judgement or defense against them-and ability to take action in line with the values". ${ }^{23}$ Psychological flexibility model has been associated with many clinical conditions as well as diabetes related chronic fatigue and quality of life. ${ }^{24}$ There are studies showing positive effect of ACT interventions, based on psychological flexibility, on stress accompanying to diabetes in children and young persons, ${ }^{25}$ depression, psychological well-being and feeling of guilt. ${ }^{26}$

Given the above mentioned data, importance of acceptance based process in coping with diabetes and associated psychological problems becomes apparent. Education and therapy programs aimed to improve psychological flexibility related skills can be considered as effective application candidates supporting the treatment. As the first example of such intervention; in a randomized controlled trial by Gregg et al. ${ }^{27}$ on patients with type- 2 diabetes, ACT+education group was compared with education alone group in terms of self-care, $\mathrm{HbA1c}$ levels, diabetes focused self-management, and psy- chological flexibility skills. Acceptance and Action Diabetes Questionnaire was developed in this study in order to evaluate psychological flexibility model that founds significant iimprovements in ACT+educational group in terms of self-care and HbAlc levels. High internal consistency (Cronbach's alpha 0.94) was found in the analysis carried out. However, as far as we know any statistical study for construct validity of the questionnaire has not yet been conducted until the time of the present study.

The aim of this study is to assess the validity and reliability of the Acceptance and Action Diabetes Questionnaire (AADQ), and to investigate whether this scale is an appropriate measurement tool for evaluation of psychological flexibility levels in a sample of patients with diabetes in Turkey. By this way, a valid evaluation tool can be provided for acceptance and psychological flexibility based interventions and studies to be conducted in patients with diabetes in Turkey.

\section{METHODS}

Ethics committee approval for the study was received from Ankara Numune Training \& Research Hospital (E-14-163/ 2015). Permission for translation of the scale to Turkish was obtained from the authors who have developed the original questionnaire, and the translation process was carried out by three researchers who have a good command of English language and have been specialized in the relevant field. Translation-retranslation process was performed by a professional translator who had no interest in psychopathology related issues and knew two languages. After the re-translation, original and re-translated versions of AADQ were compared and the final version was created.

The participants were asked to fill out Turkish forms of the Beck Depression Inventory (BDI), Problem Areas in Diabetes Questionnaire (PAID), State-Trait Anxiety Inventory (STAI-I and STAI-II), Audit of Diabetes-Dependent Quality of Life (ADDQoL) and Turkish version of Acceptance and Action Diabetes Questionnaire (TAADQ). The TAADQ were applied to nineteen participants again two weeks after the first measurement for test retest analysis (Supplementary Materials in the online-only Data Supplement).

\section{Subjects}

154 patients who were admitted to the Endocrinology Outpatient Clinic of Hitit University Corum Training and Research Hospital were offered to participate in the study between May and July 2014. They were literate and had no severe psychiatric disorders which interfere with filling correctly the scales (psychotic disorders, mental retardation etc.). 49 patients who were not willing to participate were excluded. So 105 partici- 
pant who filled informed consent form were included in the study. All of the participants were outpatients and there were no other exclusion criteria.

\section{Measures}

\section{Beck Depression Inventory (BDI)}

$\mathrm{BDI}$ is a 21-item self rating scale developed to measure severity of depressive symptoms. ${ }^{28}$ Participants score the severity of their symptoms that developed during the last 2 weeks on a 4-point Likert scale. Validity and reliability study of the Turkish form of BDI was performed by Hisli. ${ }^{29}$

\section{State-Trait Anxiety Inventory I-II (STAI-II)}

STAI contains two separate scales developed two measure state (STAI-I) and trait (STAI-II) anxiety levels. ${ }^{30}$ Responses to the questions stating severity of the feelings, thoughts and behaviours associated with state anxiety include 'not at all, somewhat, moderately so, or very much so. Whereas the responses to the items related to trait anxiety include almost never, sometimes, often, and almost always. Validity and reliability study of the Turkish form of the scale was performed by Öner and Le Compte. ${ }^{31}$

\section{Problem Areas in Diabetes Questionnaire (PAID)}

PAID is a 20-item scale developed to investigate diabetes related emotional problems in patients diagnosed with Type 1 and Type 2 diabetes. ${ }^{32}$ Questions in the scale are responded as "not a problem $=0$, minor problem $=1$, moderate problem $=2$, somewhat serious problem $=3$, and serious problem $=4$." High scores obtained indicate that the patient experiences higher diabetes related emotional stress. Validity and reliability study of the Turkish form was performed. ${ }^{33}$

\section{Audit of Diabetes-Dependent Quality of Life (ADDQoL)}

ADDQoL is designed to evaluate the severity of the effect of treatment on quality of life felt by diabetic patients. ${ }^{34}$ It is a self-report form consisting of 19 questions with a response of (a) or (b). The (a) responses are scored from -3 to +1 and the (b) responses from 0 to +3 . By multiplying the points for each question when calculating the total score, a value of -9 to +3 is obtained. A lower total score indicates a low quality of life. Validity and reliability study of Turkish form of ADDQoL conducted. ${ }^{35}$

\section{Acceptance and Action Diabetes Questionnaire (AADQ)}

The AADQ has been developed to measure acceptance of diabetes-related thoughts and feelings and the degree to which they interfere with valued action. The original form is Likert type (from '1-never true' to '7-always true') 11-item scale and higher scores indicate higher level of acceptance. ${ }^{27}$

\section{Statistical analysis}

SPSS AMOS version 23 (SPSS Inc., Chicago, IL, USA) was used in confirmatory factor analysis in order to test the construct validity of the TAADQ. ${ }^{36}$ Validity of the models can be assessed through goodness of fit of the data. ${ }^{37}$ Since chi-square $\left(\chi^{2}\right)$ is highly sensitive to the sample size, chi-square fit index is divided by the degree of freedom $\left(\chi^{2} / \mathrm{df}\right)$, and the obtained relative chi-square is used to make $\chi^{2}$ less dependent on the sample size. ${ }^{38}$ The other fit indices used in the study included the comparative fit index (CFI) ${ }^{39}$ Goodness of Fit Index (GFI), Normed Fit Index (NFI), and The Root Mean Square Error of Approximation (RMSEA).$^{40} \mathrm{CFI}$, GFI, NFI $>0.900, \chi^{2} / \mathrm{df}<5$ and RMSEA $<0.0854$ values can be considered as the acceptable fit criteria. $^{41}$

SPSS version 20.0 (IBM Corp., Armonk, NY, USA) was used for validity and reliability analysis of the other variables in the study. In order to test the reliability of the TAADQ, we used Cronbach alpha coefficient which shows the level of internal consistency, test retest correlation which indicates time invariance, and item-total correlation (ITC). The correlations between the scales were analyzed using the Pearson's correlation method in order to examine convergent and discriminant validity.

\section{RESULTS}

\section{Descriptive statistics}

A total of 105 patients participated in the present study, and 59 (56.12\%) were female. The patients' mean age was 54 (SD= $\pm 9.9)$ years. The mean duration of education was 7.65 years $(\mathrm{SD}=3.97)$. The majority $(83.3 \% \mathrm{n}=85)$ had type- 2 diabetes. The patients were a representative clinical sample with moderate-standing diabetes $(74.8 \%$ of patients with diabetes for more than 5 years), insufficient glycemic control (mean $\pm \mathrm{SD}=$ $8.02 \pm 1.91)$.

\section{Construct validity analysis}

The confirmatory factor analysis (CFA) conducted for testing the single-factor model according to original scale. According to fit indices 11-item version of TAADQ not indicated good fit. Because of low regression weights $(p>0.05)$ items 1 and 5 removed from the model. According to the fit indices, revised model with 9-item found significantly superior to previous model. Goodness-of-fit indices revealed that there is a correlated measurement error between items 10 and 11. Finally, we selected new model with 9-item (Figure 1) as the best fit for the data with RMSEA $=0.084, \mathrm{CFI}=0.942, \mathrm{GFI}=0.906$ and $\chi^{2} / \mathrm{df}=1.740$ (Table 1). Standardized regression weights (ranged 
between 0.39 and $0.88, \mathrm{p}<0.001$ ) for TAADQ were displayed in Table 2.

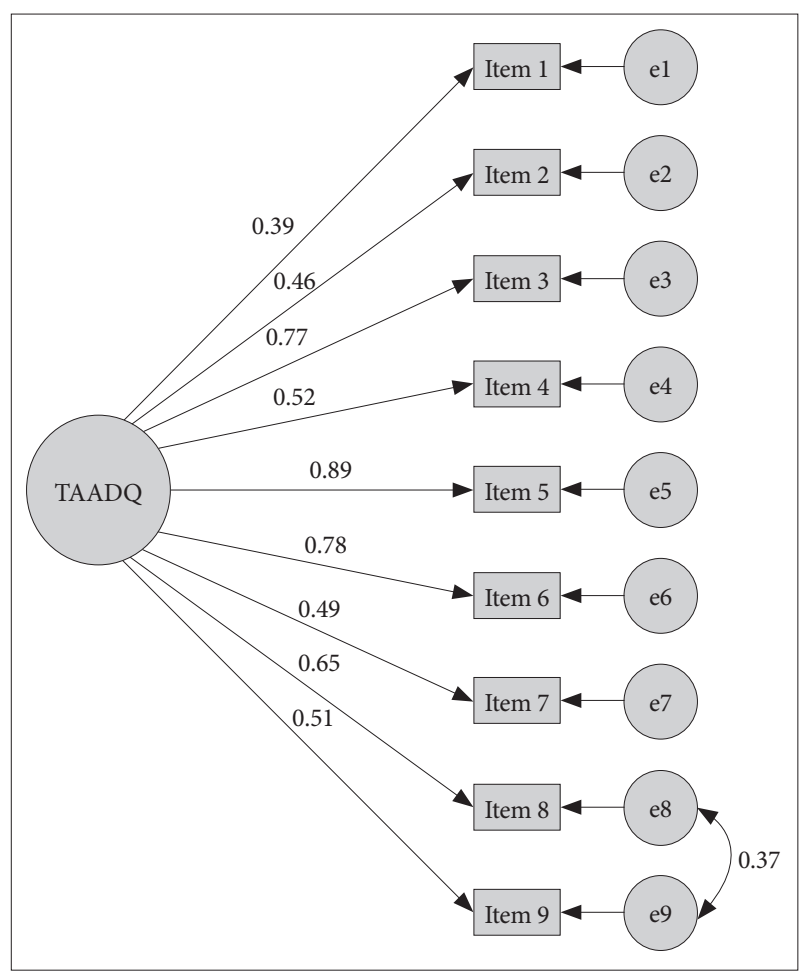

Figure 1. Standardized regression weights in a confirmatory factor analysis model of the Turkish version of the Acceptance and Action Diabetes Questionnaire.

\section{Concurrent, convergent and discriminative validity analyses}

After CFA analyses of the TAADQ it's necessary to assess concurrent, convergent and discriminant validities of the scale. Concurrent validity analyses was made with the aim of assessing the scale's correlation degrees with expected outcomes. While the TAADQ is specifically focused on psychological flexibility and experiential avoidance levels related with diabetes, ${ }^{27}$ it can be expected that TAADQ scores should be correlated with higher depressive symptoms, higher emotional stress related to diabetes and lower level quality of life. In correlation analyses we found significant relationships between TAADQ and BDI-II, PAID, and ADDQoL at low and moderate levels (respectively, $\mathrm{r}=0.405 ; \mathrm{r}=0.0485 ; \mathrm{r}=-0.246$ ) (Table 3 ).

Concerning convergent validity, it's expected to find significant correlations between TAADQ and similar constructs. In current research, we found statistically significant correlation between TAADQ and STAI-II $(r=0.415, \mathrm{p}<0.001)$ and this finding shows that higher levels of trait anxiety (also an indicator of worry ${ }^{30}$ ) has relationship with psychological inflexibility and experiential avoidance (Table 3 ).

Finally, for discriminative validity analyses we conducted a correlation analyses between TAADQ and STAI-I levels and did not find a significant relationship ( $\mathrm{r}=-0.093)$ (Table 3).

\section{Reliability analyses}

In order to determine internal consistency of TAADQ, Cron-

Table 1. Confirmatory factor analysis of Turkish version of Acceptance and Action Diabetes Questionnaire

\begin{tabular}{lcccccc}
\hline \multicolumn{1}{c}{ Single factor model } & RMSA & CFI & GFI & NFI & $\chi^{2} / \mathrm{df}$ & $\mathrm{p}$ \\
\hline 11 item & 0.134 & 0.789 & 0.819 & 0.715 & 2.857 & $<0.001$ \\
10 item (except 1. item) & 0.107 & 0.879 & 0.862 & 0.803 & 2.199 & $<0.001$ \\
9 item (except 1. and 5. item ) & 0.107 & 0.903 & 0.877 & 0.839 & 2.191 & $<0.001$ \\
9 item (measurement error revised) & 0.084 & 0.942 & 0.906 & 0.877 & 1.740 & $<0.011^{*}$ \\
\hline
\end{tabular}

${ }^{*} \mathrm{p}<0.05$. RMSA: Root Mean Square Error of Approximation, CFI: Comparative Fit Index, GFI: Goodness of Fit Index, NFI: Normed Fit Index, $\chi^{2} /$ df: Chi Square/Degrees of Free-dom

Table 2. The standard regression weights for Turkish version of Acceptance and Action Diabetes Questionnaire

\begin{tabular}{lcc}
\multicolumn{1}{c}{ Items } & $\begin{array}{c}\text { Standard regression } \\
\text { weights }\end{array}$ & $\begin{array}{c}\text { Square of multiple } \\
\text { correlations }\end{array}$ \\
\hline 1. I have thoughts and feelings about being diabetic that are distressing. & 0.391 & 0.153 \\
2. I do not take care of my diabetes because it reminds me that I have diabetes. & 0.461 & 0.212 \\
3. I eat things I shouldn't eat when the urge to eat them is overwhelming. & 0.772 & 0.596 \\
4. I avoid taking or forget to take my medication because it reminds me that I have diabetes. & 0.516 & 0.886 \\
5. I avoid stress or try to get rid of it by eating what I know I shouldn't eat. & 0.781 & 0.266 \\
6. I often deny to myself what diabetes can do to my body. & 0.492 & 0.785 \\
7. I don't exercise regularly because it reminds me that I have diabetes. & 0.647 & 0.242 \\
8. I avoid thinking about what diabetes can do to me. & 0.506 & 0.418 \\
9. I avoid thinking about diabetes because someone I knew died from diabetes. & & 0.256 \\
\hline
\end{tabular}


Table 3. Correlations of scale scores

\begin{tabular}{|c|c|c|c|c|c|c|c|}
\hline & HbAlc & ADDQoL & PAID & BDI & STAI-I & STAI-II & TAADQ \\
\hline HbAlc & 1 & & & & & & \\
\hline ADDQoL & 0.222 & 1 & & & & & \\
\hline PAID & 0.032 & $-0.487^{* *}$ & 1 & & & & \\
\hline BDI & -0.154 & $-0.245^{*}$ & $0.612^{* *}$ & 1 & & & \\
\hline STAI-I & -0.154 & $-0.318^{* *}$ & $0.535^{* *}$ & $0.720^{* *}$ & 1 & & \\
\hline STAI-II & 0.258 & 0.131 & -0.044 & -0.120 & -0.058 & 1 & \\
\hline TAADQ & 0.258 & $-0.246^{*}$ & $0.485^{* *}$ & $0.405^{* *}$ & $0.415^{*}$ & -0.093 & 1 \\
\hline
\end{tabular}

${ }^{*} \mathrm{p}<0.05,{ }^{*} \mathrm{p}<0.01$. ADDQoL: Audit of Diabetes-Dependent Quality of Life, PAID: Problem Areas in Diabetes Questionnaire, BDI: Beck Depression Inventory, STAI: State-Trait Anxiety Inventory, TAADQ: Turkish version of Acceptance and Action Diabetes Questionnaire

Table 4. Item-total statistics

\begin{tabular}{ccccc}
\hline Item & Mean (if item deleted) & Variance (if item deleted) & Corrected item total correlations & Cronbach alpha (if item deleted) \\
\hline 1 & 20.08 & 108.436 & 0.407 & 0.836 \\
2 & 21.91 & 110.752 & 0.375 & 0.838 \\
3 & 21.38 & 100.296 & 0.675 & 0.805 \\
4 & 22.62 & 112.950 & 0.455 & 0.829 \\
5 & 22.08 & 101.186 & 0.754 & 0.799 \\
6 & 22.52 & 106.790 & 0.682 & 0.810 \\
7 & 21.75 & 107.073 & 0.462 & 0.829 \\
8 & 21.06 & 95.824 & 0.668 & 0.805 \\
9 & 21.42 & 99.342 & 0.541 & 0.822 \\
\hline
\end{tabular}

bach's alpha correlation analysis method was used. After removing of two items according to CFA, Cronbach's alpha coefficient was found 0.836 , which indicates a good internal consistency. All items were positively correlated with total score of the scale and Table 4 displays the descriptive statistics for TAADQ items, corrected item-total correlations and the value of Cronbach's alpha if item deleted.

For the purpose of determining the temporal stability of TAADQ, the scale was applied to 19 patients with two weeks intervals by using the test-retest method. When the test-retest correlations were investigated for each item of TAADQ, all of the items were found to have a value between 0.47 and 0.86 (Table 5).

\section{DISCUSSION}

AADQ which is a scale enabling evaluation of psychological flexibility levels of diabetic patients, allows assessment of the attitudes of diabetics toward the disease and associated problems both in clinical practice and studies. In this study, we investigated whether the Turkish form of scale is a valid and reliable assessment tool in Turkish population.

When calculating sample size for the analysis of construct validity of the scale, it is generally recommended that the number of persons should be higher than the number of variables,
Table 5. Test-retest correlations

\begin{tabular}{ccc}
\hline TAADQ items $(\mathrm{N}=19)$ & $\mathrm{r}$ & $\mathrm{p}$ \\
\hline 1 & 0.508 & $0.026^{*}$ \\
2 & 0.582 & $0.009^{*}$ \\
3 & 0.683 & $0.001^{*}$ \\
4 & 0.867 & $0.000^{*}$ \\
5 & 0.695 & $0.001^{*}$ \\
6 & 0.564 & $0.012^{*}$ \\
7 & 0.638 & $0.003^{*}$ \\
8 & 0.471 & $0.042^{*}$ \\
9 & 0.657 & $0.002^{*}$ \\
\hline
\end{tabular}

${ }^{*} \mathrm{p}<0.05$. TAADQ: Turkish version of Acceptance and Action Diabetes Questionnaire, r: correlation coefficient

and should be at least 5 to 10 for each variable. ${ }^{42}$ For this reason, at the beginning of the study we targeted to include 110 persons based on the 11-item AADQ, ultimately reached to 105 persons, thought that the above mentioned condition was met. In the confirmatory factor analysis carried out in order to test TAADQ has not a single-factor construct as its original version; it was found that model fit values of the 11-item version were not at an acceptable level, following respective removal of the 1st and 5th items from the scale, 9-item 3rd method obtained was found to have acceptable values.

CFA was then applied to test whether AADQ has a single- 
factor construct. CFA also allows to detect measurement errors. Errors showing high correlations may include methodological reasons, use of similar words, overlapping of the contents, and difficulty in understanding, etc. ${ }^{37}$ In our study, according to the results of CFA, TAADQ was found to have a single-factor construct like its original version. A high correlation was found between the 8th and 9th items in terms of the measurement errors. The use of similar words such as "I avoid thinking of..." and emphasis on avoidance attitude in both items may explain the high correlation level determined and effect of the method.

Reliability of a scale can be tested through test retest analysis, internal consistency coefficient, and item total score correlation analysis. ${ }^{43}$ Analyses (test retest correlation, item-total correlation with 2-week interval, cronbach alpha coefficient, and item-total scale point analyses) were performed on 9-item version. Looking test retest correlations of AADQ, correlation coefficients of each item were found to be between 0.47 and 0.86 , which indicated that the scale items did not show significant change over time. Cronbach alpha coefficient, and itemtotal scale point analyses were used to assess the internal consistency. ${ }^{42}$ In our study, alpha coefficient of the AADQ was found as 0.83 , and Schmitt et al. ${ }^{17}$ who studied the original scale's reliability and validity found similarly alpha value as 0.82 . Accordingly, it can be said that the internal consistency is high both in original and Turkish forms of the scale. In item-total scale point analysis which is performed to test reliability of $A A D Q$, it is reported that the coefficients should be higher than 0.30 , and the items that do not comply with this rule may be removed from the scale. ${ }^{44}$ Looking to our results; the coefficients of item-total scale point analysis varied between 0.27 and 0.75 , and we found unnecessary to remove any item.

Concurrent validity is used to evaluate whether the measurement tool measure the expected results. In the present study, significant correlations between severity of depressive symptoms, quality of life levels, and diabetes related emotional stress and AADQ, support concurrent validity of the scale. Because there are studies reporting that avoidance from negative inner life events causes more stress, ${ }^{45}$ and is associated with higher depression levels and lower quality of life. ${ }^{46,47}$ In order to test convergent validity of the scale; correlation between AADQ and STAI-II scale which was developed to measure the levels of trait anxiety and worry was analyzed, and a significant correlation was observed. The correlation between these two scales may not expected to be much strong because ACT's psychological inflexibility mode ${ }^{23}$ included other psychopathological processes (eg. experiential avoidance, cognitive fusion, poor self-perception, decreased contact with the values etc.) in addition to anxiety. This findings of our study may be considered as a result which could be an evidence for convergent validity of AADQ.

For divergent validity of AADQ; its correlation with STAII scale, developed to assess state anxiety, was assessed. Because AADQ was designed to measure avoidance attitudes rather than situtational signs, it is not expected to be affected by crosssectional symptoms. As an evidence for the Divergent validity of AADQ, we did not find a significant correlation between the two scales.

Our study has some limitations. Relatively small sample size may have an impact on the study results. Also we had no sufficient rates of the patients with type- 1 and type- 2 diabetes for creating two separate groups, and we can not assess possible differences in psychological flexibility between two diabetes types. The complications of diabetes may lead to more severe depressive symptoms and anxiety and less psychological flexibility but in this study the patients with diabetes were not classified according to complications of diabetes; this can be another limitation. Further comprehensive studies with a larger sample size or two type-1 and type- 2 diabetes group or classified according to complications of diabetes should be conducted for this purpose.

In conclusion; our study demonstrates that the TAADQ has sufficient psychometric properties. Measurement of diabetes related psychological flexibility/inflexibility may be useful in development and implementation of interventions for increasing quality of life in diabetic persons in Turkey. So TAADQ will be a powerfull tool in assessing psychological flexibility in diabetes patients.

\section{Supplementary Materials}

The online-only Data Supplement is available with this article at https://doi.org/10.30773/pi.2019.02.26.2.

\section{Conflicts of Interest}

The authors have no potential conflicts of interest to disclose.

\section{Author Contributions}

Karadere and Yavuz conceived of the presented idea, developed the theory, determined the methodology and analyzed the data. Karadere, Asafov and Küçükler contributed to finding cases, collection and entry of data. All authors discussed the results and contributed to the final manuscript.

\section{ORCID iDs}

Mehmet Emrah Karadere

https://orcid.org/0000-0002-1404-9839

\section{REFERENCES}

1. Das-Munshi J, Stewart R, Ismail K, Bebbington PE, Jenkins R, Prince MJ. Diabetes, common mental disorders, and disability: findings from the UK National Psychiatric Morbidity Survey. Psychosom Med 2007; 69:543-550.

2. Abegunde DO, Mathers CD, Adam T, Ortegon M, Strong K. The burden and costs of chronic diseases in low-income and middle-income countries. Lancet 2007;370:1929-1938.

3. Lloyd CE, Roy T, Begum S, Mughal S, Barnett AH. Measuring psycho- 
logical well-being in South Asians with diabetes; a qualitative investigation of the PHQ-9 and the WHO-5 as potential screening tools for measuring symptoms of depression. Diabet Med 2012;29:140-147.

4. Johnson B, Eiser C, Young V, Brierley S, Heller S. Prevalence of depression among young people with Type 1 diabetes: a systematic review. Diabet Med 2013;30:199-208.

5. Holt RIG, De Groot M, Golden SH. Diabetes and depression. Curr Diabet Rep 2014;14:491.

6. Hasan SS, Mamun AA, Clavarino AM, Kairuz T. Incidence and risk of depression associated with diabetes in adults: evidence from longitudinal studies. Community Ment Health J 2014;51:204-210.

7. DeJean D, Giacomini M, Vanstone M, Brundisini F. Patient experiences of depression and anxiety with chronic disease: a systematic review and qualitative meta-synthesis. Ont Health Technol Assess Ser 2013;13:1-33.

8. Rosenthal MH. The challenge of comorbid disorders in patients with depression. J Am Osteopath Assoc 2003;103:S10-S15.

9. Zahiroldini AR, Sedighi G. Depression among 100 diabetics referring to university hospitals. Pajouhesh Dar Pezeshki 2003;27:203-207.

10. Peyrot M, Burns KK, Davies M, Forbes A, Hermanns N, Holt R, et al. Diabetes Attitudes Wishes and Needs 2 (DAWN2): a multinational, multistakeholder study of psychosocial issues in diabetes and person-centred diabetes care. Diabetes Res Clin Pract 2013;99:174-184.

11. Grimaldi A. The acceptance of the diabetic disease. Ann Endocrinol (Paris) 2003;64(3 Suppl):S22-S26.

12. Rhee MK, Slocum W, Ziemer DC, Culler SD, Cook CB, El-Kebbi IM, et al. Patient adherence improves glycemic control. Diabetes Educ 2005;31: 240-250.

13. Uchendu C, Blake H. Effectiveness of cognitive-behavioural therapy on glycaemic control and psychological outcomes in adults with diabetes mellitus: a systematic review and meta-analysis of randomized controlled trials. Diabet Med 2017;34:328-339.

14. Elliott S. Cognitive behavioural therapy and glycaemic control in diabetes mellitus. Pract Diabetes 2012;29:67-71.

15. Grey M, Boland EA, Davidson M, Li J, Tamborlane WV. Coping skills training for youth with diabetes mellitus has long-lasting effects on metabolic control and quality of life. J Pediatr 2000;137:107-113.

16. Garay-Sevilla ME, Malacara JM, Gutiérrez-Roa A, González E. Denial of disease in Type 2 diabetes mellitus: its influence on metabolic control and associated factors. Diabet Med 2001;16:238-244.

17. Schmitt A, Reimer A, Kulzer B, Haak T, Gahr A, Hermanns N. Assessment of diabetes acceptance can help identify patients with ineffective diabetes self-care and poor diabetes control. Diabet Med 2014;31:14461451.

18. Richardson A, Adner N, Nordström G. Persons with insulin-dependent diabetes mellitus: acceptance and coping ability. J Adv Nurs 2001;33:758763.

19. Kamody RC, Berlin KS, Rybak TM, Klages KL, Banks GG, Ali JS, et al. Psychological flexibility among youth with type 1 diabetes: relating patterns of acceptance, adherence, and stress to adaptation. Behav Med 2018;44:271-279.

20. Whitebird RR, Kreitzer MJ, O'Connor PJ. Mindfulness-based stress reduction and diabetes. Diabetes Spectr 2009;22:226-230.

21. Bohlmeijer ET, Fledderus M, Rokx TAJJ, Pieterse ME. Efficacy of an early intervention based on acceptance and commitment therapy for adults with depressive symptomatology: evaluation in a randomized controlled trial. Behav Res Ther 2011;49:62-67.

22. Hayes SC, Strosahl KD, Wilson KG. Acceptance and Commitment Therapy: An Experiential Approach to Behavior Change: New York: Guilford Press; 1999.

23. Hayes SC, Luoma JB, Bond FW, Masuda A, Lillis J. Acceptance and commitment therapy: model, processes and outcomes. Behav Res Ther 2006; 44:1-25.

24. Momeniarbat F, Karimi J, Erfani N, Kiani J. The role of neuroticism and psychological flexibility in chronic fatigue and quality of life in patients with type 2 diabetes. Rom J Diabetes Nutr Metab Dis 2017;24:137-148.

25. Moazzezi M, Moghanloo VA, Moghanloo RA, Pishvaei M. Impact of acceptance and commitment therapy on perceived stress and special health self-efficacy in seven to fifteen-year-old children with diabetes mellitus. Iran J Psychiatry Behav Sci 2015;9:31-36.

26. Ataie Moghanloo V, Ataie Moghanloo R, Moazezi M. Effectiveness of acceptance and commitment therapy for depression, psychological wellbeing and feeling of guilt in 7-15 years old diabetic children. Iran J Pediatr 2015;25:e2436

27. Gregg JA, Callaghan GM, Hayes SC, Glenn-Lawson JL. Improving diabetes self-management through acceptance, mindfulness, and values: a randomized controlled trial. J Consult Clin Psychol 2007;75:336-343.

28. Beck AT, Ward CH, Mendelson MM, Mock JJ, Erbaugh JJ. An inventory for measuring depression. Arch Gen Psychiatry 1961;4:561-571.

29. Hisli N. The validity and reliability of Beck Depression Inventory in university students. Turk J Psychol 1989:3-13.

30. Spielberger CD, Gorsuch RL, Lushene RE. Manual for State-Trait Anxiety Inventory. California: Consulting Psychologist Press; 1970.

31. Öner N, Le Compte A. State-Trait Anxiety Inventory Handbook. Istanbul: Boğaziçi University Publications; 1985.

32. Polonsky WH, Anderson BJ, Lohrer PA, Welch G, Jacobson AM, Aponte JE, et al. Assessment of diabetes-related distress. Diabetes Care 1995; 18:754-760.

33. Huis In T Veld EMJ, Makine C, Nouwen A, Karşda C, Kadioğlu P, Karşda $\mathrm{K}$, et al. Validation of the Turkish version of the problem areas in diabetes scale. Cardiovasc Psychiatry Neurol 2011;2011:315068.

34. Bradley C, Todd C, Gorton T, Symonds E, Martin A, Plowright R. The development of an individualized questionnaire measure of perceived impact of diabetes on quality of life: the ADDQoL. Qual Life Res 1999;8: 79-91.

35. Demirci H, Cinar Y, Bayram N, Bilgel N. Quality of life in type II diabetic patients in primary health care. Dan Med J 2012;59:A4468.

36. Byrne BM. Structural Equation Modeling with AMOS : Basic Concepts, Applications, and Programming. New York, NY: Routledge Academic; 2010.

37. Brown TA. Confirmatory Factor Analysis for Applied Research. New York NY: Guilford Press; 2006.

38. Jon WH. The analysis of covariance structures: goodness-of-fit indices. Sociol Methods Res 1983;11:325-344.

39. Bentler PM. Comparative fit indexes in structural models. Psychol Bull 1990;107:238-246.

40. Hu LT, Bentler P. Evaluating Model Fit. In: Hoyle RH, Editor. Structural Equation Modeling. Concepts, Issues, and Applications. London: Sage, 1995, p.76-99.

41. Munro BH. Statistical Methods for Health Care Research. Vol. 1. Philadelphia: Lippincott Williams \& Wilkins; 2005.

42. Kazım Ö. Statistical Data Analysis with Package Programs. Eskişehir: Kaan Bookstore; 2004.

43. Erefe İ. Nature of Data Collection Tools. In: Erefe İ, Editor. Principles and Methods of Research in Nursing. Istanbul: Odak Ofset, 2002, p.169-188.

44. Pallant J. SPSS Survival Manual: A Step by Step Guide to Data Analysis Using SPSS. London: McGraw-Hill Education (UK); 2013.

45. Hayes SC, Wilson KG, Gifford EV, Follette VM, Strosahl K. Experiential avoidance and behavioral disorders: a functional dimensional approach to diagnosis and treatment. J Consult Clin Psychol 1996;64:1152-1168.

46. Bond FW, Hayes SC, Baer RA, Carpenter KM, Guenole N, Orcutt HK, et al. Preliminary psychometric properties of the acceptance and action questionnaire-II: a revised measure of psychological inflexibility and experiential avoidance. Behav Ther 2011;42:676-688.

47. Yavuz F, Ulusoy S, Iskin M, Esen FB, Burhan HS, Karadere ME, et al. Turkish version of Acceptance and Action Questionnaire-II (AAQ-II): a reliability and validity analysis in clinical and non-clinical samples. Klinik Psikofarmakol Bülteni/Bull Clin Psychopharmacol 2016;26:397408. 


\section{DIYYABETLILLER/ŞEKER HASTALARI İÇINN KABUL VE EYLEM FORMU}

Aşağıda bir dizi ifade bulunmaktadır. Her bir ifadenin sizin için ne kadar doğru olduğunu yanında yazan rakamı yuvarlak içine alarak belirtiniz. Seçiminizi yapmak için aşağıdaki cetveli

\section{kullanınız.}

\begin{tabular}{c|c|c|c|c|c|c}
1 & 2 & 3 & 4 & 5 & 6 & 7 \\
\hline $\begin{array}{c}\text { Hiçbir zaman } \\
\text { doğru değil }\end{array}$ & $\begin{array}{c}\text { Çok nadiren } \\
\text { doğru }\end{array}$ & Nadiren doğru & Bazen doğru & Stklkla doğru & $\begin{array}{c}\text { Neredeyse her } \\
\text { zaman doğru }\end{array}$ & Daima doğru
\end{tabular}

1. Şeker hastası olma ile ilişkili sıkıntı veren duygu ve düşüncelere sahibim. $\quad \begin{array}{lllllll}1 & 2 & 3 & 4 & 5 & 6 & 7\end{array}$

2. Şeker hastalığıma dikkat etmiyorum çünkü bana şeker hastası olduğumu hatırlatiyor.

$\begin{array}{lllllll}1 & 2 & 3 & 4 & 5 & 6 & 7\end{array}$

3. Yeme arzusu karşı konulmaz olduğunda yememem gereken şeyleri yiyorum.

$\begin{array}{lllllll}1 & 2 & 3 & 4 & 5 & 6 & 7\end{array}$

4. İlaçlarımı almaktan kaçınıyorum ya da almayı unutuyorum çünkü bu durum bana şeker hastalığım olduğunu hatırlatıyor.

$\begin{array}{lllllll}1 & 2 & 3 & 4 & 5 & 6 & 7\end{array}$

5. Yememem gerektiğini bildiğim şeyleri yiyerek gerginlikten kaçınıyorum ya da kurtulmaya çalışıyorum.

$\begin{array}{lllllll}1 & 2 & 3 & 4 & 5 & 6 & 7\end{array}$

6. Şeker hastalığının vücuduma yapabileceklerini sık sık inkar ederim reddederim.

$\begin{array}{lllllll}1 & 2 & 3 & 4 & 5 & 6 & 7\end{array}$

7. Düzenli olarak egzersiz yapmıyorum çünkü bana şeker hastalığım olduğunu hatırlatıyor.

$\begin{array}{lllllll}1 & 2 & 3 & 4 & 5 & 6 & 7\end{array}$

8. Şeker hastalığının bana neler yapabileceğini düşünmekten kaçınıyorum. $\quad \begin{array}{lllllll}1 & 2 & 3 & 4 & 5 & 6 & 7\end{array}$

9. Diyabet hakkında düşünmekten kaçınıyorum çünkü tanıdığım biri şeker $\quad \begin{array}{lllllll}1 & 2 & 3 & 4 & 5 & 6 & 7\end{array}$ hastalığından öldü.

*(1. madde hariç tüm maddeler ters puanlıdır) 